\title{
Influence of Teacher Motivation on Provision of Quality Early Childhood Education in Njoro Divison, Nakuru County, Kenya
}

\author{
Agnes Wanjiru Ngotho ${ }^{1}$, Dr. Yattani Buna ${ }^{2}$ \\ ${ }^{1,2}$ Department of Early Childhood Studies, School of Education, Kenyatta University, Kenya
}

\begin{abstract}
The benefits associated with quality education have been acknowledged globally. Quality early childhood education programmes have been found to help to build a strong foundation for the child's physical, mental, emotional and social development that prepare them for a lifetime. In regard to this early childhood education was believed to prepare children for primary school. The purpose of this study was to investigate the influence of teacher motivation on the provision of quality early childhood education. Descriptive survey research design was used. The target population for the study was pre-school teachers and head teachers in Njoro Division, Nakuru County. The division has 84 ECE centres. The respondents comprised of 84 Head teachers, 168 ECDE teachers forming a target population of 252 respondents. Stratified sampling method and simple random sampling was used to select the sample size for the study. The sample size was $50 \%$ of 168 teachers (84) and 84 pre-school teachers (42) were selected giving a total of 126 respondents. Questionnaires and interview schedules were used to obtain data from the field. Questionnaires were piloted at to the ECDE centres in Njoro Division comprising of nine respondents which were not included in the final study to test validity and reliability of the instrument. Quantitative data was analysed using descriptive statistics which included mean, frequencies and percentages and presented in terms of tables, graphs and charts. Qualitative data was coded and analysed thematically based on the study objectives. The study established that teacher motivation positively and significantly influenced the provision of quality early childhood education. The study concludes that teacher motivation is critical to the success in enhancing quality ECDE education. This because teachers are the most important implementers, since they interface with the learners who have special education needs. The study recommends that special motivational strategies that target ECDE teachers on ECDE programs education should be implemented. All teachers who work in an inclusive setting should be given a special allowance.
\end{abstract}

Keywords: Teacher Motivation, Quality Early Childhood Education

\section{INTRODUCTION}

$\mathrm{E}$ arly Childhood Education (ECE) represents the true beginning of formal education for all children and the quality of care and education which a child receives at this crucial age will determine to a great extent the level of his or her physical and cognitive development in the future (Ige, 2011). Similarly children who attend preschool or other early education programs have been found to have enhanced cognitive, verbal, and social development, which is maintained into the first few years of school. Barnett and Steven (2015) argue that these early learning experiences are crucial determining factors for emotional and intellectual development and will ultimately affect how well a child will perform in school. Therefore, the competence of ECDE teacher is important in mounting the life of preschool children.

Provision of quality Early Childhood is a major challenge globally. Although all the countries require prospective teachers at this level to have completed initial education studies, most preschool teaching staff has not done so. In El Salvador, Neugebauer and Goodeve (2009) observe that just $10.2 \%$ of teachers working in nursery education have an honours degree, while in Nicaragua, Verdisco, NaslundHadley, Regalia \& Zamora (2010) note that the non-formal system of pre-primary education, which has the greatest coverage in the country, is mainly staffed by people who have completed primary schooling only. This suggests that efforts need to be made to systematize the initial level and coordinate it with the rest of the education system.

In Kenya, According to OECE (2012) report, constant communication between parents and teachers was associated with more sensitive teacher-to-child and parent-to-child and/or teacher interactions. Hyde and Kabiru (2013) in a study on management and funding of education in Kenya showed that the Ministry of Education was responsible for the overall administration, policy and professional guidance, grants for training staff, curriculum development and conducting research and evaluation. The study also observed that the government was concerned with teacher deployment, promotion and coordinated health programmes like immunizations and feeding schemes for children. While the above study sought to establish the role of educators in the ministry of education and other stakeholders the current study will strive to find out factors affecting provision of quality ECE.

Guthrie (2012) notes that instructional materials, if used efficiently and actively facilitate the learning process in classrooms. However, the situation is not good in most preschools. Firstly, only the lower quality and the less quantity of instructional resources are provided to pre-schools. In this way, the availability of instructional resources is strained and 
very limited. Secondly, pre-school teachers are not trained for using instructional resources. Waithaka (2005) emphasizes the importance of training ECDE teachers as he observes that most ECDE centers in Kenya lay emphases on academic work, giving little or no time at all for learners to interact with instructional materials. He further observes that in Kenya preschool children are subjected to academic work due to pressure from parents who would like to see their children read and write within weeks upon joining pre-school.

Early Childhood Development and Education policies stress the use of plenty of relevant instructional resources to develop the totality of the child (NACECE, 2013). Learning has been ineffective in most ECDE centres with children having difficulties in mastering reading, manipulative, numeric and interpersonal skills despite several studies on instructional resources being carried out (Cheruiyot \& Kosgei, 2011). Cave and Mulloy (2010) emphasized the importance of teacher preparedness in terms of professional records preparation, academic and professional training levels of the pre-school teachers for quality standards in ECDE.

\section{STATEMENT OF THE PROBLEM}

There are major concerns in the county such as access and affordability of quality education in these ECE centers, inadequate physical infrastructure and low staffing levels. The increase of children attending ECE centers necessitate need for increased investments in education facilities and services to cope with the growing demand. Despite the growing importance of Early Childhood Education, there are number of challenges that have continued to pull down the quality of education in ECE in Nakuru County, giving evidence to the current study. Therefore, this study sought to investigate teacher motivation on quality in ECE in Njoro Division, Nakuru County, Kenya.

\section{LITERATURE REVIEW}

Teacher motivation was found to be imperative because it leads to contentment and attainment of goals and objectives (Jesus \& Conboy, 2011). On the other hand, lack of teacher motivation was found to lead to teacher absenteeism or spending time to looking for other job opportunities. Indire and Handon (2012) study showed that education is affected by teacher morale and attrition and further recommended that the government should undertake measures to improve teachers' salaries, the condition of service, opportunities for career advancement and retaining quality teachers.

In a study carried out by Sanchard (2013) in Kenya involving 200 students indicated that 29 of the students declared that teaching was seen as a stepping stone for other job opportunities. The study further found that Kenyan teachers seeking to secure a better job opportunity would first prefer teaching as they wait for that chance to come. So this necessitates the need to improve the working environment of ECE teachers, attend to their preferences, incentives and future aspirations in order to maximize their potential and retaining them for quality ECE programmes. Similarly, Waithaka (2003) carried out a study on how job satisfaction of pre-school teachers influences quality education in preschools established that majority of the pre-school teachers were satisfied with appropriate school management and how the management related with their pupils. The study also revealed that pre-school teacher were not motivated as they suffered poor working conditions of the pre-school teacher in Kenya, lack of retirement benefits, low salary and job insecurity.

Makoti (2015) carried out a study in Kwale District on the relationship between terms and conditions of service and motivation of pre-school teachers established a significant relationship between conditions of service of pre-school teachers under different sponsors and the level of their motivation. The study further established that career development, poor salary, job insecurity and training had also a significant relationship with pre-school teacher motivation. The study recommended that the government need to place pre-school teachers under a governing body such as Teachers Service Commission (TSC) and establish proper guidelines on how to improve their terms and working conditions order to enhance their productivity. Whereas the above study sought to establish the relationship between terms and conditions of service and teacher motivation, the current study will seek to establish how teacher motivation will influence the quality of early childhood education.

Ndani and Kimani (2011) study carried out in Thika SubCounty focused on factors influencing motivation of early childhood development teachers. The study established that the level of motivation of more than half of the pre-school teacher was below average and they recommended that in order to improve the teaching and learning environment and the terms and conditions of service of ECE teachers, there should be a good collaboration with the Ministry of Education and the community.

Ngaroga (2009) study carried out in Kigumo Division in Murang'a District on factors contributing job to satisfaction and dissatisfaction in pre-primary school teachers established that pre-primary school teachers were not satisfied with the method of promotion and with teaching and learning materials and housing. The study also revealed that many ECE centres in Kigumo Division lacked basic facilities like classrooms, furniture, play grounds, modern toilets and safe drinking water. Similarly, Ndani and Kimani (2011) study established that preschool microsystems were insufficient to sustain children's development. For instance, they suggested that most of the physical environment in their local of study as not suitable for children learning. Therefore, the current study seeks to find out how teacher motivational factors influence the provision of quality ECE.

Akuoko, Dwumah and Baba (2012) study examined how teacher motivation affects quality education delivery and found a significant relationship between teacher motivation 
and quality education delivery and there was no significant difference in terms of motivation between urban and periurban teachers in the metropolis. Majority of the teachers joined the service because of the interest they had in teaching. But the level of motivation was too low. The study recommended that the living and working conditions of teachers should be improved and the opportunity for career advancement should be simplified for teachers to upgrade their professional knowledge and skills.

Naomi (2015) study focused on the the impact of teachers' motivation on the improvement of the quality of teaching and learning in public primary schools in Ilala District, Tanzania. The study established that the role of teachers help the pupils marks scores to be high, that factors contributed to low teachers morale were lack of recognition of teachers work, lack of involvement in decision making, lack of appreciation from educational officers and heads of schools, low salary and poor working conditions. To improve the teaching and learning teachers should be given incentives to attract their attention consequently improve performance.

Zaslow, Tout, Maxwell and Clifford (2014) study examined the role of professional development in creating high quality preschool education. The study revealed that tightening the linkages will involve moving from a focus on professional development as a status variable to direct and detailed consideration of the content of professional development and practices to assure that desired behaviors are actually implemented in the early childhood classroom, as well as an appropriate balance between learning and practice in professional preparation.

Busingye (2016) study examined on teachers' motivation as determinant of inclusive education in early childhood centers, Kampala District, Uganda. Findings revealed that low salaries, lack of professional development and poor conditions of service led to low job satisfaction and neutral attitudes that prevented teachers from using the skills they had to implement inclusive education in ECD centres. It was concluded that stakeholders in education should seriously address de-motivating factors to empower teachers implement inclusive education more effectively.

\section{RESEARCH METHODOLOGY}

Descriptive survey research design was used. The target population for the study was pre-school teachers and head teachers in Njoro Division, Nakuru County. The division has 84 ECE centres. The respondents comprised of $84 \mathrm{Head}$ teachers, 168 ECDE teachers forming a target population of 252 respondents. Stratified sampling method and simple random sampling was used to select the sample size for the study. The sample size was $50 \%$ of 168 teachers (84) and 84 pre-school teachers (42) were selected giving a total of 126 respondents. Questionnaires and interview schedules were used to obtain data from the field. Questionnaires were piloted at to the ECDE centres in Njoro Division comprising of nine respondents which were not included in the final study to test validity and reliability of the instrument. Quantitative data was analysed using descriptive statistics which included mean, frequencies and percentages and presented in terms of tables, graphs and charts. Qualitative data was coded and analysed thematically based on the study objectives.

\section{FINDINGS}

The findings of the study sought to determine the influence of teacher motivation on the provision of quality ECE in Njoro Division, Nakuru County, Kenya. In order to achieve this objective interview schedules and questionnaires were used to find out the pre-school teachers and head teachers views on whether teacher motivation influenced quality early provision. The findings are presented in Table 1.

Table 1: Teacher Motivation

\begin{tabular}{|c|c|c|c|c|c|c|c|}
\hline Statement & SA & $\mathrm{A} \%$ & $\mathrm{~N} \%$ & $\mathrm{D} \%$ & $\mathrm{SD} \%$ & M\% & Std.Dev \\
\hline $\begin{array}{l}\text { The amount of salary paid to ECE teachers positively influences } \\
\text { provision of quality ECD education }\end{array}$ & 46.7 & 24.6 & 7.4 & 12.3 & 9.0 & 4.10 & 1.228 \\
\hline $\begin{array}{l}\text { Continuous promotion of ECE teachers positively influences provision } \\
\text { of quality ECE education }\end{array}$ & 27.9 & 57.4 & 6.6 & 3.3 & 4.9 & 4.00 & 0.816 \\
\hline $\begin{array}{l}\text { Continuous promotion of ECE teachers positively influences provision } \\
\text { of quality ECE education }\end{array}$ & 37.7 & 53.3 & 4.1 & 3.3 & 1.6 & 4.23 & 0.620 \\
\hline $\begin{array}{l}\text { The school organizes trips and tours for teachers in order to motivate } \\
\text { them }\end{array}$ & 33.6 & 50.8 & 12.3 & 3.3 & 0.0 & 4.05 & 0.846 \\
\hline Teachers are given leave absence in case they have a reason to justify & 44.3 & 44.3 & 0.0 & 3.3 & 8.2 & 4.48 & 0.640 \\
\hline $\begin{array}{l}\text { The school give advance payment from the school in case one has a } \\
\text { financial problem }\end{array}$ & 37.7 & 49.2 & 9.0 & 4.1 & 0.0 & 4.45 & 0.677 \\
\hline The school provides teachers with lesson preparation materials & 54.1 & 18.9 & 0.0 & 19.7 & 7.4 & 4.60 & 0.545 \\
\hline Aggregate Score & 40.3 & 42.6 & 5.6 & 7.0 & 4.4 & 4.27 & 0.753 \\
\hline
\end{tabular}

Source: Research Data (2019)

From the results in Table 1, the aggregate score mean of 4.27 indicated that the head teachers strongly agreed that teacher motivation influence provision of quality early childhood education in Njoro Divison, Nakuru County with a significance variance of 0.753 . Majority $(40.3 \%)$ of the head teachers strongly agreed on this statement, $42.6 \%$ agreed, 
$5.6 \%$ neutral, $7.0 \%$ disagreed and $4.4 \%$ strongly disagreed. These findings are in line with the findings of a study carried by Jesus and Conboy (2011) which established that teacher motivation was an imperative because it leads to contentment and attainment of goals and objectives.

The mean of 4.60 indicated that the school provides teachers with lesson preparation materials with a significance variance of $0.545 .54 .1 \%$ of the head teachers strongly agreed on this statement, $18.9 \%$ agreed, $19.7 \%$ disagreed and $7.4 \%$ strongly disagreed. These findings concur with the findings of Ndani and Kimani (2011) study established that the level of motivation of more than half of the pre-school teacher was below average and they recommended that in order to improve the teaching and learning environment and the terms and conditions of service of ECE teachers, there should be a good collaboration with the Ministry of Education and the community.

The mean of 4.05 indicated that the school organizes trips and tours for teachers in order to motivate them with a significance variance of $0.846 .33 .6 \%$ of the head teachers strongly agreed on this statement, 50.8\% agreed, $12.3 \%$ neutral and 3.3\% disagreed. These findings concur with Waithaka (2003) study on how job satisfaction of pre-school teachers influences quality education in pre-schools established that majority of the pre-school teachers were satisfied with appropriate school management and how the management related with their pupils. The study also revealed that pre-school teacher were not motivated as they suffered poor working conditions of the pre-school teacher in Kenya, lack of retirement benefits, low salary and job insecurity.

The head teachers agreed that recognizing the achievement of ECE teachers has a positive influence on the provision of quality ECE education, the amount of salary paid to ECE teachers positively influences provision of quality ECD education, the school organizes trips and tours for teachers in order to motivate them and that continuous promotion of ECE teachers positively influences provision of quality ECE education as indicated by mean score of $4.23,4.10,4.05$ and 4.00 respectively with respective variance of $0.620,1.128$, 0.846 and 0.816 . These findings are supported by the findings of a study carried out by Akuoko et al. (2012) which found a significant relationship between teacher motivation and quality education delivery and there was no significant difference in terms of motivation between urban and periurban teachers in the metropolis.

From the interview schedules, ECDE teachers indicated that they are paid salaries as low as 5000 Kshs. per month which they indicated that the salary is not paid promptly. They cited reasons as the lack of the recognition of ECDE programs and also due to the low status of the ECDE teachers. The respondents also indicated that parents who are supposed to fund the program do not pay fees on time. The respondents indicated that the salary paid to them is not enough. They indicated the reasons based to the time they spent with the pupils and the increasing number of the pupils in the ECDE centre. All the respondents indicated that since they were employed they have never been promoted. They indicated that this could be attributed to lack of career advancement by the schools and lack of government concern about the ECDE teachers. The respondents agreed that been awarded through recognition during school Barazas but they have not been awarded any certificate of achievement since they were employed.

\section{CONCLUSIONS AND RECOMMENDATIONS}

The study concludes that teacher motivation is critical to the success in enhancing quality ECDE education. This because teachers are the most important implementers, since they interface with the learners who have special education needs. ECDE teacher were not motivated as they suffered poor working conditions in the centre, lack of retirement benefits, low salary and job insecurity. Career development, poor salary, job insecurity and training had also a significant relationship with ECDE teacher motivation.

The study recommends that special motivational strategies that target ECDE teachers on ECDE programs education should be implemented. All teachers who work in an inclusive setting should be given a special allowance. A policy of motivating teachers who teach in ECDE setting should be written and implemented in all centres. In order to improve the quality of inclusive education, there is a dire need to spend on teacher training in order to produce competent teachers.

\section{REFERENCES}

[1] Akuoko, K. O., Dwumah, P., \& Baba, W. M. (2012). Teacher motivation and quality education delivery: A study of public basic schools in Tamale metropolis in Ghana. International Journal of Social Science \& Interdisciplinary Research, 1(12), 29-46

[2] Barnett, W. \& Steven, H. (2015). Long Term Effects of Early Childhood Programs on Cognitive and School Outcomes. The Future of Children, 5(3), 12-18

[3] Busingye, E. (2016). Teachers' motivation as Determinant of Inclusive Education in Early Childhood Centers, Kampala District, Uganda (Doctoral Dissertation, School of Education, Kenyatta University)

[4] Cave, A. \& Mulloy, M. (2010). A Qualitative Examination of Teacher Perceptive National Forum of Education. Administration and supervision Journal, 27(4), 213-215

[5] Cheruiyot, K. \& Kosgei, N. (2011). Child growth and development (Conception-3 years) Nairobi: Enterprise Publishers

[6] Guthrie, E. R. (2012). The Psychology of Learning ( $7^{\text {th }}$ Ed). New York; Harper \& Row

[7] Hyde, A. L. \& Kabiru, M. N. (2013). Early childhood as an important strategy to improve learning outcomes. Grand Baie Mauritius: Association for the development of education in Africa (ADEA).

[8] Ige, A. M. (2011). The challenges facing early childhood care, development and education (ECCDE) in an era of universal basic education in Nigeria. Early Childhood Education Journal, 39(2), 161-167

[9] Indire, F. \& Handon, J. (2012). Secondary Level Teachers Supply and Demand in Kenya. Michigan Board of Trustees

[10] Jesus, S. \& Conboy, J. (2011). A Stress Management Course to Prevent Teacher Distress. International Journal of Educational Management, 3, 131-137 
[11] Makoti, N. M. (2005). Terms and conditions of service and their relationship to motivation of preschool teachers in Kwale District, Kenya. Unpublished MEd thesis, Kenyatta University

[12] NACECE, (2013). Guidelines for early childhood development in Kenya. Nairobi: K.I.

[13] Naomi, A. M. (2015). The impact of teachers' motivation on the improvement of the quality of teaching and learning in public primary schools in Ilala District, Tanzania. Open University of Tanzania

[14] Ndani, M. N., \& Kimani, E. N. (2011). Factors influencing early childhood development teachers' motivation in Thika district, Kenya. African journal of teacher education, 1(1), $415-426$

[15] Neugebauer, R., \& Goodeve, E. (2009). global trends in early childhood education: 2009.

Exchange, 34-40

[16] Ngaroga, J. M. (2014). A study of the Factors that Contribute to Job Satisfaction and Dissatisfaction Among Primary School
Teachers of Kigumo Division in Murang'a District. Unpublished MA Thesis, University of Nairobi

[17] [Sanchard, R. (2013). Kenyan Education Review. A Journal of the Faculty of Education. University of Nairobi, 1-26

[18] Verdisco, A., Naslund-Hadley, E., Regalia, F., \& Zamora, A. (20010). Integrated childhood development services in Nicaragua. Child Health and Education, 1(2), 104-

[19] Waithaka, E. (2003). Job Satisfaction of Pre-school Teachers in Thika Municipality by School Sponsorship. An unpublished MED Thesis, Kenyatta University

[20] Waithaka, E. (2005). Play and social emotional development in young children in Thika Town: Unpublished $\mathrm{PhD}$ Thesis: Nairobi: Kenyatta University

[21] Zaslow, M., Tout, K., Maxwell, K., \& Clifford, R. (2014). The role of professional development in creating high quality preschool education. Washington, DC: Brookings Institution 